\title{
Using monitoring data to model herbicides exported to the Great Barrier Reef, Australia
}

\author{
Lewis, S.E. ${ }^{1}$, R. Smith ${ }^{2}$ J.E. Brodie ${ }^{1}$ Z.T. Bainbridge ${ }^{1}$ A.M. Davis ${ }^{1}$ and R. Turner ${ }^{2}$ \\ ${ }^{1}$ Catchment to Reef Research Group, Australian Centre for Tropical Freshwater Research, James Cook \\ University, Townsville 4811 Australia. \\ ${ }^{2}$ Catchment Water Sciences, Department of Environment and Resource Management, Ecosciences Precinct, \\ GPO Box 2454, Brisbane 4001 Australia. \\ Email: stephen.lewis@jcu.edu.au
}

\begin{abstract}
:
The run-off of agricultural herbicides which inhibit photosystem II (PSII) in plants, have been identified as key pollutants of concern by the Great Barrier Reef Water Quality Protection Plan 2009 ('Reef Plan'). As such, a target has been set for 2013 to reduce the annual load of PSII herbicides exported to the Great Barrier Reef (GBR) by 50\%. Historically, monitoring of PSII herbicide loads entering the GBR has been spatially and temporally limited. More recently, monitoring has been extended both on a spatial and temporal scale; however, not all catchments that export to the GBR are monitored. Hence, an adequate data set required to calculate the PSII herbicide loads to assess the progress towards Reef Plan's target does not currently exist and therefore a modeling approach was developed. The approach utilised existing monitoring data to calculate herbicide run-off coefficients $\left(\mathrm{g} \cdot \mathrm{ha}^{-1}\right)$ for key agricultural land uses of the whole GBR catchment area (i.e. sugarcane, grazing, dry land cereal crops and horticulture). Run-off coefficients were calculated for the six most commonly detected PSII herbicides in GBR catchments; diuron, used for sugarcane and dry land cereal crops; atrazine, used for sugarcane, dry land cereal crops and horticulture; hexazinone, used for sugarcane and horticulture; ametryn, used for sugarcane; simazine, used for dry land cereal crops; and tebuthiuron, used for grazing. We calculated an 'average' annual load for each of the monitored catchments from available monitoring data of either 'event' or annual loads (which commonly was available over a few years and captured considerable inter-annual discharge variability) coupled with the mean discharge of each catchment that was specified in the latest online discharge data. Each river was categorised by the predominant land use in its catchment. To calculate an annual run-off coefficient an assumption was made that the entire herbicide load was sourced from the predominant land use. A regionally specific runoff coefficient for each of the key land uses in the GBR was then calculated from the average of the catchment coefficients. Coefficients were then applied using the QLUMP 1999 land use data for each basin of the GBR catchment area to estimate a mean annual load. The modeled load calculations were validated with monitoring data from a combination of passive and grab sampling. Standard deviation of these runoff coefficients were used to estimate the uncertainties of these total PS-II herbicide loads exported from each GBR basin.
\end{abstract}

Keywords: $\quad$ Herbicides, runoff coefficients, Great Barrier Reef, loads, diuron, atrazine, tebuthiuron 


\section{INTRODUCTION}

The runoff of photosystem-II (PS-II) inhibiting herbicides to the Great Barrier Reef (GBR) has been identified as a key management priority under the Reef Water Quality Protection Plan (Reef Plan, 2009). The five PS-II herbicides targeted in Reef Plan (2009) include diuron, atrazine, ametryn, hexazinone and tebuthiuron. Indeed, a growing number of studies have documented the presence of these PS-II herbicides in the GBR lagoon (e.g. Lewis et al., 2009; Shaw et al., 2010; Kennedy et al., in press) and, at times, concentrations may exceed levels that ecotoxicological studies show invoke negative effects on marine plants (Haynes et al., 2000; Jones, 2005; Magnusson et al., 2010). While the Reef Plan (2009) has set an aspirational target to reduce the loadings of total PS-II herbicides to the GBR lagoon by half by 2013, the estimates of the 'current' or 'baseline' PS-II export is poorly constrained and so this precise target cannot be assessed. Moreover, catchment-wide monitoring programs to quantify the PS-II export to the GBR have only commenced since 2009/10 (Smith et al., in press) and prior to this time PS-II data are only available for a limited number of catchments.

Previous studies have developed 'runoff coefficients' for key land uses in the GBR catchment area using preexisting PS-II herbicide load data (Maughan et al., 2008; Kroon et al., 2010; Waterhouse et al., in press), although these estimates have only considered these 5 herbicides (or six including simazine) as a total load and have not presented the individual herbicide load data separately. This is problematic for risk assessments as these herbicides all have different levels of toxicity to non-target species and need to be considered separately. Moreover, the suitability of applying specific land use coefficients for these herbicides across the different regions is questionable. For example, the use of diuron, atrazine, hexazinone and ametryn in sugarcane lands varies across the Wet Tropics, Burdekin, Mackay-Whitsunday and Burnett-Mary regions and so a 'standard' coefficient across the sugarcane industry in the GBR would produce loads of relatively low reliability. Similarly, tebuthiuron is thought to be predominately used in the Brigalow Belt country located within the cattle grazing lands of the Fitzroy and southern Burdekin catchments and this coefficient should not be applied to other grazing lands within the GBR catchment area. Finally the previous load estimates do not consider the uncertainty inherent within these PS-II loads.

In this study, we develop herbicide runoff coefficients for diuron, atrazine, hexazinone, ametryn, tebuthiuron and simazine for four key land uses in the GBR including sugarcane (separate coefficients for Wet Tropics, Burdekin, Mackay Whitsunday and Burnett regions), grazing (separate coefficients for Brigalow grazing and 'coastal grazing'), dry land cereal cropping and horticulture to model PS-II herbicide export to the GBR. We compare these results with the previous load estimates and suggest further refinements to the model that addresses key limitations/knowledge gaps so that it can be utilized as a tool to estimate 'baseline' PS-II herbicide loads. These estimates can be used to assess the effectiveness of improved farming systems being implemented across the GBR catchment area.

\section{MODEL INPUT DATA AND COEFFICIENT DEVELOPMENT}

All available PS-II load data (published and unpublished) were compiled from catchment monitoring programs across the GBR catchment area up to the 2009/10 water year (Mitchell et al., 2005; Lewis et al., 2007; Rohde et al., 2008; Lewis et al., 2009; Packett et al., 2009; Davis et al., in press; ACTFR, unpublished; DERM, unpublished). Loads were all calculated using linear interpolation techniques and the calculated loads were derived from a mixture of flow events and annual loads. This dataset is the most comprehensive available for the GBR. We note that several sites have been sampled for three years or more and thus the sampling has captured considerable inter-annual discharge variability. An event mean concentration (EMC) or annual mean concentration (AMC) was calculated for each site and an average was taken for sites that had been sampled over multiple years. This EMC or AMC was coupled with mean annual flow data taken from the Queensland Department of Environment and Resource Management 'Watershed' website (DERM, 2011) to calculate an average annual load for each of the sampled sites. We note that while some paddock-scale data were available, they have been excluded from this analysis as the runoff coefficients would be much higher as this monitoring typically targets runoff following herbicide application. Therefore this dataset does not capture the larger scale variability in herbicide application across an entire catchment area.

The most current land use data (in ha) upstream of each of the sampling sites (either QLUMP 1999 or 2004) were used to calculate runoff coefficients from the average annual PS-II load data (in kg). The sampling sites were grouped according to their major land uses including 'sugar cane' for the South Johnstone and Tully Rivers (Wet Tropics Sugar), Haughton River and upper Barratta Creek (Burdekin Sugar), Pioneer and O'Connell Rivers and Sandy Creek (Mackay Whitsunday Sugar) and Burnett River (Burnett Sugar). The annual average loads of diuron, total atrazine (comprised of atrazine plus degradation products desethyl atrazine and desisopropyl atrazine), hexazinone and ametryn at these sites were all assumed to be sourced from sugar cane and the load (in $\mathrm{kg}$ ) was divided by the area of sugar cane (in ha) to derive a coefficient ( $\mathrm{g}$ $\mathrm{ha}^{-1}$ ) for sugar cane land use for each site. A mean and standard deviation (the lower confidence $1 \sigma$ interval) 
was calculated (Table 1) where multiple sites existed within the region (i.e. Wet Tropics, Burdekin and Mackay Whitsunday). The assumption that the loads of diuron, atrazine, hexazinone and ametryn were all sourced to sugar is reasonable given that sugar cane is the predominant crop (intensive agriculture) at each of the sampled sites and that other intensive agriculture (e.g. bananas and pawpaws in the South Johnstone and Tully Rivers) do not use these chemicals widely (if at all). Many studies have also sourced these herbicides to sugar (e.g. Lewis et al., 2009). Annual average loads of total atrazine and hexazinone in the Don River and Euri Creek were assumed to be sourced from horticulture and as such these loads were used to develop runoff coefficients for horticulture land use (Table 1). This assumption is reasonable given that no sugar is grown in the Don River catchment and only a small area of sugar is present in Euri Creek. While a review of pesticide use in eight of the major crops grown in this region suggested that atrazine is used in sweet corn crops, none of these crops reported the use of hexazinone (Lewis and Glendenning, 2009) and so another crop/source may be required (there are several other minor crops grown in the district). In any case, hexazinone was the most prevalent herbicide detected in the Don River and Euri Creek over the sampling periods.

Table 1. Calculated runoff coefficients used to model PS-II herbicide export to the GBR.

\begin{tabular}{|c|c|c|c|c|c|c|c|c|c|}
\hline \multirow{2}{*}{ Site } & \multicolumn{3}{|c|}{$\begin{array}{l}\text { Predominant land use } \\
\text { Area (ha) }\end{array}$} & \multicolumn{6}{|c|}{ PS-II Herbicide export (g/ha) } \\
\hline & Grazing & sugar & cropping & Ametryn & Atrazine & Diuron & Hexazinone & Tebuthiuron & Simazine \\
\hline Tully River & & 14,210 & & & 2.67 & 12.22 & 8.95 & & \\
\hline South Johnstone River & & 5,600 & & & 2.51 & 3.33 & & & \\
\hline Wet Tropics sugar & & & & & $7.59 \pm 7.2$ & $7.77 \pm 6.3$ & $8.95 \pm 0.9$ & & \\
\hline Upper Barratta Creek & & 10,144 & & 0.4282 & 1.24 & 5.38 & 0.146 & & \\
\hline Haughton River* & 157,248 & 9,173 & & 0.0705 & 4.93 & 3.92 & 0.005 & 0.005 & \\
\hline Burdekin sugar & & & & $0.249 \pm 0.25$ & $8.08 \pm 4.5$ & $4.65 \pm 1.0$ & $0.076 \pm 0.10$ & & \\
\hline Pioneer River & & 45,540 & & 1.22 & 9.36 & 0.44 & 3.969 & & \\
\hline Sandy Creek & & 14,046 & & 0.304 & 5.25 & 18.29 & 5.154 & & \\
\hline O'Connell River & 19,312 & 2,703 & & & 21.96 & 46.09 & 5.123 & & \\
\hline $\begin{array}{l}\text { Mackay Whitsunday } \\
\text { sugar }\end{array}$ & & & & $0.760 \pm 0.64$ & $12.19 \pm 8.7$ & $31.61 \pm 13.9$ & $4.749 \pm 0.7$ & & \\
\hline Burnett River* & $2,650,620$ & 22,089 & & & 0.470 & 0.257 & 0.242 & 0.002 & \\
\hline Burnett sugar & & & & & $0.47 \pm 0.05$ & $0.26 \pm 0.03$ & $0.24 \pm 0.02$ & & \\
\hline Fitzroy River & $11,132,074$ & & 950,299 & & 0.808 & 0.153 & 0.057 & 0.091 & 0.076 \\
\hline Comet River & $1,282,320$ & & 164,400 & & 1.76 & & 0.065 & 0.030 & \\
\hline Belyando River & $3,305,592$ & & 17,527 & & 0.798 & & & 0.024 & \\
\hline Suttor River & 937,908 & & 115,201 & & 0.121 & & & 0.058 & \\
\hline $\begin{array}{l}\text { Total dryland } \\
\text { cropping/grazing }\end{array}$ & & & & & $0.872 \pm 0.7$ & $0.15 \pm 0.06$ & $0.06 \pm 0.01$ & $0.051 \pm 0.03$ & $0.076 \pm 0.01$ \\
\hline Don River & 101,116 & & 2,598 & & 1.12 & & 0.437 & & \\
\hline Euri Creek & 34,606 & & 2,998 & & & & 0.444 & & \\
\hline Total cropping/grazing & & & & & $1.12 \pm 0.68$ & & $0.441 \pm 0.01$ & $0.0034 \pm 0.01$ & \\
\hline
\end{tabular}

The loads of atrazine, diuron, hexazinone and simazine in the Belyando, Suttor, Fitzroy and Comet Rivers were all assumed to be sourced to dry land cereal cropping in these catchments. This assumption is reasonable given that dry land cereal cropping is the only major land use in these catchments where these chemicals are registered for use and was also shown in Packett et al. (2009). In addition, tebuthiuron loads from these same Rivers were likely sourced to Brigalow Belt cattle grazing lands. The nature of the Brigalow country requires the control of tree/shrub regrowth to ensure its productivity for cattle production and as such tebuthiruon is used more widely in these lands compared to other beef grazing areas of the GBR catchment area. Therefore a mean runoff coefficient with standard deviation $(1 \sigma)$ for atrazine, diuron, hexazinone and simazine was calculated for these dryland cropping lands while the same process was performed for tebuthiuron in 'Brigalow Belt' grazing land types (Table 1). While the runoff coefficients 
developed for atrazine and tebuthiuron are considered reasonable given that these herbicides were prevalent in every monitored site in these catchments, the coefficients for diuron, hexazinone and simazine are much less certain given they were detected sporadically in the Fitzroy and Comet Rivers. Tebuthiuron was also detected in the 'coastal' catchments of the O'Connell, Haughton and Burnett Rivers and as such coefficients have also been developed for these particular grazing lands (Lewis et al., 2007; Rohde et al., 2008). The loads of tebuthiuron in the O'Connell River measured in 2004 to 2007 (Rohde et al., 2008) represent much higher coefficients than those even calculated for the Brigalow grazing sites and as such these data were excluded from our analysis. Thus, only the coefficients calculated for tebuthiuron loss from 'coastal grazing lands' in the Haughton and Burnett Rivers were used in this study (Table 1). We recommend further monitoring in the O'Connell River to ascertain if these anomalously high tebuthiuron losses are continuing in this catchment.

\section{MODEL RUN}

The runoff coefficients developed for the six herbicides for the key land uses in the GBR catchment area using the pre-existing monitoring data were used to calculate annual mean loads for the Basins across the GBR catchment area (Table 2). To maintain consistency across the catchment area, the 1999 QLUMP land use data (reported in Brodie et al., 2003) were used exclusively in our analysis as an updated dataset (2004) was not available across the entire region. The $1 \sigma$ standard deviation of the runoff coefficients were used to produce an uncertainty estimate based around each of the individual herbicide loads and these values have been added and included with the total PS-II load. We note due to the relatively high standard deviations in the herbicide runoff coefficients calculated across land uses in the GBR catchment area that this has resulted in PS-II load uncertainty typically $\sim \pm 50 \%$. Coefficients of variation for other pollutant loads such as total suspended sediments can commonly be in the order of $\pm 20 \%$ (Lewis et al., in review) and so these relatively high uncertainties are not unexpected. In fact, with the uncertainties in total flows, the variability in PS-II runoff concentrations across the same land uses within regions and the relatively low accuracy and precision of the herbicide analysis in the laboratory $( \pm 15-20 \%)$ (compared to sediment and nutrient data), uncertainties of $> \pm 50 \%$ may even be expected.

\section{DISCUSSION AND CONCLUSIONS}

The development of regionally specific runoff coefficients for the key land uses across the GBR catchment area provide the most reliable estimates to date of PS-II herbicide export to the GBR lagoon. The addition of uncertainty values within our model and the inclusion of loads of individual herbicides also represent a considerable advancement on the previous modeling results. Interestingly, our PS-II load estimates sit between the previous estimates of Maughan et al. (2008), Kroon et al. (2010) and Waterhouse et al. (in press), with the Maughan et al. (2008) study at the lower end of the uncertainty bounds of our estimates and the latter models within (or even higher than) the upper bounds (Table 2). Unfortunately, the high uncertainties (typically in the order of $\pm 50 \%$ ) in the total PS-II loads will make the assessment of catchment targets (i.e. a reduction in PS-II loads by 50\%) difficult. However, long-term monitoring programs could potentially measure this reduction with some confidence at individual sites. Moreover, the runoff coefficients calculated in this study could be used as a 'baseline' and thus a target of half the runoff coefficient could be set. The reasons for the high variability in the load data as well as the land use coefficients across the different catchments of the GBR are not well established but may reflect a response to different soil types across the regions, different weeds and pressures or simply the amount of marketing and promotion of a product within each region. Current research is examining these links.

This model could be improved with the incorporation of additional load data (particularly in regions with limited monitoring), the use of the latest land use mapping data (when it becomes available across the entire catchment area) and also with the development of additional coefficients for other land uses such as bananas, pawpaws and plantation forestry. The inclusion of the 2004 QLUMP data could for example, potentially highlight the land use that is sourced to the hexazinone loads in Euri Creek. We note that while the herbicide simazine is used in plantation forestry and has been detected in various monitoring programs (Bubb et al., 2003; Bainbridge et al., 2009; Leslie et al., 2010), this herbicide is only used in the plant/establishment stages (first crop year) and is currently being phased out of the industry (K. Bubb pers comm., 2011). The total area of pine plantation forestry in the GBR catchment area is very low compared to the other predominant agricultural land uses and as such the loadings of simazine from plantation forestry is expected to be very low (Leslie, 2010). As more reliable load data become available it would be instructive in the future to develop runoff coefficients for other herbicides which are regularly detected in the GBR monitoring programs such as 2,4-D and metalachlor, expanding the range of coefficients outside of the PS-II herbicide suite and allowing for more detailed risk assessments of pesticides to be developed. Furthermore, once more localized land use coefficients can be developed these can be then compared to data on application rates as well as soil types and climate regimes. 
Lewis et al., Using monitoring data to model herbicides exported to the Great Barrier Reef, Australia

Table 2. Modelled PS-II herbicide loads exported from each GBR Basin to the GBR lagoon with uncertainties in this study and compared to previous model runs.

\begin{tabular}{|c|c|c|c|c|c|c|c|c|c|}
\hline Basin & $\begin{array}{c}\text { Diuron } \\
\text { (kg) }\end{array}$ & $\begin{array}{l}\text { Atrazine } \\
(\mathrm{kg})\end{array}$ & $\begin{array}{c}\text { Hexazi } \\
\text {-none } \\
\text { (kg) }\end{array}$ & $\begin{array}{c}\text { Ametryn } \\
(\mathrm{kg})\end{array}$ & $\begin{array}{l}\text { Tebuthi } \\
\text {-uron } \\
\text { (kg) }\end{array}$ & $\underset{(\mathbf{k g})}{\operatorname{Simazine}}$ & Total PS-II (kg) & $\begin{array}{l}\text { Maughan } \\
\text { et al. } \\
2008(\mathrm{~kg})\end{array}$ & $\begin{array}{c}\text { Waterhousel } \\
\text { Kroon et al. } \\
\text { (in press) } \\
\text { (kg) }\end{array}$ \\
\hline Jacky Jacky Creek & 0 & 0 & 0 & 0 & 0 & 0 & $0 \pm 0$ & 0 & \\
\hline Olive-Pascoe Rivers & 0 & 0 & 0 & 0 & 0 & 0 & $0 \pm 0$ & 0 & \\
\hline Lockhart River & 0 & 0 & 0 & 0 & 0 & 0 & $0 \pm 0$ & 0 & \\
\hline Stewart River & 0 & 0 & 0 & 0 & 0 & 0 & $0 \pm 0$ & 0 & \\
\hline Normanby River & 0 & 1 & 1 & 0 & 6 & 0 & $8 \pm 3$ & 0 & \\
\hline Jeannie River & 0 & 0 & 0 & 0 & 0 & 0 & $0 \pm 0$ & 0 & \\
\hline Endeavour River & 0 & 0 & 0 & 0 & 0 & 0 & $0 \pm 0$ & 0 & \\
\hline Daintree River & 12 & 12 & 14 & 0 & 0 & 0 & $38 \pm 23$ & 19 & 84 \\
\hline Mossman River & 27 & 26 & 31 & 0 & 0 & 0 & $83 \pm 49$ & 71 & 181 \\
\hline Barron River & 4 & 20 & 11 & 0 & 0 & 0 & $36 \pm 10$ & 75 & 52 \\
\hline Mulgrave-Russell Rivers & 261 & 255 & 301 & 0 & 0 & 0 & $817 \pm 482$ & 364 & 1780 \\
\hline Johnstone River & 350 & 345 & 404 & 0 & 0 & 0 & $1099 \pm 647$ & 634 & 2578 \\
\hline Tully River & 170 & 169 & 197 & 0 & 0 & 0 & $537 \pm 315$ & 251 & 1162 \\
\hline Murray River & 61 & 60 & 71 & 0 & 0 & 0 & $193 \pm 113$ & 169 & 418 \\
\hline Herbert River & 555 & 551 & 643 & 0 & 2 & 0 & $1750 \pm 1028$ & 455 & 3799 \\
\hline Black River & 4 & 7 & 0 & 0 & 0 & 0 & $12 \pm 5$ & 8 & 44 \\
\hline Ross River & 0 & 1 & 0 & 0 & 0 & 0 & $2 \pm 0.3$ & 0 & 1 \\
\hline Haughton River & 315 & 552 & 7 & 17 & 1 & 0 & $892 \pm 397$ & 545 & 3607 \\
\hline Burdekin River & 71 & 168 & 5 & 3 & 256 & 6 & $509 \pm 284$ & 76 & 1153 \\
\hline Don River & 53 & 33 & 13 & 1 & 1 & 0 & $102 \pm 42$ & 0 & 106 \\
\hline Proserpine River & 774 & 299 & 117 & 19 & 0 & 0 & $1209 \pm 587$ & 279 & 1782 \\
\hline O'Connell River & 1085 & 419 & 163 & 26 & 0 & 0 & $1694 \pm 823$ & 242 & 2260 \\
\hline Pioneer River & 1439 & 555 & 216 & 35 & 0 & 0 & $2246 \pm 1091$ & 502 & 2648 \\
\hline Plane Creek & 1737 & 670 & 261 & 42 & 0 & 0 & $2710 \pm 1317$ & 757 & 3329 \\
\hline Styx River & 0 & 0 & 0 & 0 & 1 & 0 & $1 \pm 0.5$ & 0 & 23 \\
\hline Shoalwater Creek & 7 & 3 & 1 & 0 & 0 & 0 & $12 \pm 6$ & & 20 \\
\hline Water Park Creek & 0 & 0 & 0 & 0 & 0 & 0 & $1 \pm 0.3$ & & 13 \\
\hline Fitzroy River & 114 & 648 & 45 & 0 & 614 & 56 & $1478 \pm 923$ & 911 & 2195 \\
\hline Calliope River & 0 & 0 & 0 & 0 & 1 & 0 & $1 \pm 0.4$ & 0 & 18 \\
\hline Boyne River & 0 & 1 & 0 & 0 & 1 & 0 & $2 \pm 0.4$ & 0 & 0 \\
\hline Baffle Creek & 0 & 3 & 1 & 0 & 1 & 0 & $6 \pm 1$ & 0 & 20 \\
\hline Kolan River & 4 & 8 & 4 & 0 & 1 & 0 & $16 \pm 5$ & 101 & 100 \\
\hline Burnett River & 6 & 98 & 40 & 0 & 9 & 0 & $154 \pm 22$ & 318 & 300 \\
\hline Burrum River & 8 & 16 & 8 & 0 & 1 & 0 & $33 \pm 10$ & & 400 \\
\hline Mary River & 3 & 65 & 26 & 0 & 1 & 0 & $95 \pm 11$ & & 150 \\
\hline
\end{tabular}

\section{ACKNOWLEDGMENTS}

We acknowledge the efforts of the scientists and volunteers that have undertaken much of the field pesticide data collection. In particular, Bob Packett, Ken Rohde, and Bronwyn Masters deserve special recognition for their monitoring in the Fitzroy and Mackay Whitsunday regions, respectively. The project is supported by the Australian and State Government's Reef Rescue Research and Development Program, the National Environmental Research Program and the Reef Protection Program (Research and Development). 
Lewis et al., Using monitoring data to model herbicides exported to the Great Barrier Reef, Australia

\section{REFERENCES}

Bainbridge, Z.T., Brodie, J.E., Faithful, J.W., Sydes, D.A., and Lewis, S.E. (2009). Identifying the land-based sources of suspended sediments, nutrients and pesticides discharged to the Great Barrier Reef from the Tully Basin, Queensland, Australia. Marine and Freshwater Research, 60, 1081-1090.

Brodie, J., McKergow, L.A., Prosser, I.P., Furnas, M., Hughes, A.O., and Hunter, H. (2003). Sources of sediment and nutrient exports to the Great Barrier Reef World Heritage Area. ACTFR Report No. 03/11, Australian Centre for Tropical Freshwater Research, James Cook University, Townsville, 208 p.

Bubb, K.A., Frayne, P.F., Wittmer, T.R., and Grimmett, J.L. (2003). Efficacy of atrazine and simazine application over harvest residue in Queensland's subtropical softwood plantations. Australian Forestry, 66, 102-107.

Davis, A.M., Lewis, S.E., Bainbridge, Z.T., Brodie, J.E., Glendenning, L., and Turner, R. (in press). Pesticide residue transport and partitioning under event flow conditions in the lower Burdekin region, Australia. Marine Pollution Bulletin.

DERM. (2011). Watershed website: http://www.derm.qld.gov.au/watershed/index.html

Haynes, D., Ralph, P., Prange, J., and Dennison, B. (2000). The impact of the herbicide diuron on photosynthesis in three species of tropical seagrass. Marine Pollution Bulletin, 41, 288-293.

Jones, R. (2005). The ecotoxicological effects of photosystem II herbicides on corals. Marine Pollution Bulletin, 51, 495-506.

Kennedy, K., Schroeder, T., Shaw, M. Haynes, D., Lewis, S., Bentley, C., Paxman, C., Carter, S., Brando, V., Bartkow, M., and Mueller, J. (in press). Photosystem-II herbicides on the Great Barrier Reef- results from up to five years of monitoring and a preliminary comparison with remote sensing derived water quality parameters. Marine Pollution Bulletin.

Kroon, F., Kuhnert, P., Henderson, B., Henderson, A., Turner, R., Huggins, R., Wilkinson, S., Abbott, B., Brodie, J., and Joo, M. (2010). Baseline pollutant loads to the Great Barrier Reef. CSIRO: Water for a Healthy Country Flagship Report series ISSN: 1835-095X. 41 pp.

Leslie, E. (2010). The influence of climate and land use on water quality in a small tropical catchment, north Queensland. Master's Thesis, Australian National University, 78 pp.

Lewis, S., and Glendenning, L. (2009). A pesticide risk-assessment for horticultural lands of the Bowen/Lower Burdekin region. ACTFR Report No. 09/27 for the NQ Dry Tropics NRM, ACTFR, James Cook University.

Lewis, S., Davis, A., Brodie, J., Bainbridge, Z., McConnell, V., and Maughan, M. (2007). Pesticides in the lower Burdekin and Don catchments: 2005-2007. ACTFR Report No. 07/05 For the Burdekin Dry Tropics NRM. ACTFR, James Cook University.

Lewis, S.E., Brodie, J.E., Bainbridge, Z.T., Rohde, K., Davis, A., Masters, B., Maughan, M., Devlin, M., Mueller, J., and Schaffelke, B. (2009). Herbicides: A new threat to the Great Barrier Reef. Environmental Pollution, 157, 2470-2484.

Lewis, S.E., Bainbridge, Z.T., Kuhnert, P.M., Sherman, B.S., Henderson, B., Cooper, M., and Brodie, J.E. (in review). Trapping efficiencies of reservoirs: can the classic algorithms work in river systems with highly variable intra-annual inflows? Water Resources Research.

Maughan, M., Brodie, J., and Waterhouse, J. (2008). Reef Exposure model for the Great Barrier Reef Lagoon. ACTFR Report Number 07/19. Australian Centre for Tropical Freshwater Research, James Cook University, Townsville.

Mitchell, C., Brodie, J., and White, I. (2005). Sediments, nutrients and pesticide residues in event flow conditions in streams of the Mackay Whitsunday Region, Australia. Marine Pollution Bulletin, 51, 23-36.

Packett, R., Dougall, C., Rohde, K., and Noble, R. (2009). Agricultural lands are hot-spots for annual runoff polluting the southern Great Barrier Reef lagoon. Marine Pollution Bulletin, 58, 976-985.

Reef Plan, Reef Water Quality Protection Plan Secretariat. (2009). Reef Water Quality Protection Plan 2009: For the Great Barrier Reef World Heritage Area and adjacent catchments, Queensland Department of Premier and Cabinet, Brisbane.

Rohde, K., Masters, B., Fries, N., Noble, R., Carroll, C. (2008). Fresh and marine water quality in the Mackay Whitsunday region; 2004/05 to 2006/07. Queensland Department of Natural Resources and Water for the Mackay Whitsunday Natural Resource Management Group, Australia.

Shaw, M., Furnas, M.J., Fabricius, K., Haynes, D., Carter, S., Eaglesham, G., and Mueller, J.F. (2010). Monitoring pesticides in the Great Barrier Reef. Marine Pollution Bulletin, 60, 113-122.

Smith, R., Middlebrook, R., Turner, R., Huggins, R., Vardy, S., Warne, M. (in press). Large-scale pesticide monitoring across Great Barrier Reef catchments - Paddock to Reef Integrated Monitoring, Modelling and Reporting Program. Marine Pollution Bulletin. 